\title{
Intestinal Disaccharidase Activity in Rosacea
}

\author{
E. PATON,* M.B., CH.B. ; E. MURRAY, † B.SC. ; W. C. WATSON, $¥$ M.D., PH.D., M.R.C.P., M.R.C.P.GLASG.
}

Brit. med. F., 1966, 1, 459-460

Symptoms of intestinal discomfort attributed to carbohydrate intolerance (Kendall, 1926) have long been recognized as a feature of rosacea (Eastwood, 1928), but attempts to alleviate them and improve the facial flushing with a low-carbohydrate diet have been only partially successful (Stokes and Beerman, 1932).

Recently intestinal disaccharidase deficiency has been identified as one cause of carbohydrate intolerance (Durand, 1958 ; Auricchio et al., 1963 ; Kern et al., 1963 ; Dahlqvist, 1964 ; McMichael et al., 1965; Sheehy and Anderson, 1965).

The disaccharidases are produced and act within the cells of the intestinal epithelium (Miller and Crane, 1961). Enzyme deficiencies may be found singly or combined, and in normal or diseased epithelium. Histologically demonstrable smallbowel disease is a common feature of rosacea (Watson et al., 1965), so that disaccharidase deficiency might occur and account wholly or partly for the alimentary disturbance which is found in $75 \%$ of patients.

\section{Methods}

Of the 60 patients previously reported (Watson et al., 1965) 20 were restudied. They were selected to give proportional representation of the five histological categories already defined and a typically high incidence of alimentary symptoms (see Table). Thus 6 of the 20 had diarrhoea and dyspepsia, and 11 had one of these symptoms. That is, $17(85 \%)$ of the 20 had gastro-intestinal symptomatology.

Biopsy of the upper jejunum was performed as previously described (Watson et al., 1965). The position of the Crosby capsule was checked radiologically in every case. The tissue was quickly washed in saline and spread on filter paper but not blotted, as this always removes some of the superficial epithelium. After 10 seconds it was weighed on a microtorsion balance and then homogenized in at least $1 \mathrm{ml}$. of ice-cold distilled water. If the piece of tissue weighed more than $10 \mathrm{mg}$. the volume was adjusted to give a tissue concentration of 10 $\mathrm{mg} . / \mathrm{ml}$.

Disaccharidase activity (maltase, sucrase, and lactase) was assayed immediately thereafter, exactly as described by Dahlqvist (1964), except that the maltase assays were carried out at a $1 / 10$ dilution. In our experience the $p H$ optimum for all three disaccharidases varies from 5.5 to 6.5 , but the results obtained, are not significantly dissimilar, and are most frequently maximal at $p \mathrm{H} 6$, the $p \mathrm{H}$ used in the standard method.

Control assays were carried out on 12 ambulant convalescent patients without bowel symptoms or disease, eating a normal ward diet. In most cases a piece of tissue was sent for confirmatory histology.

In four of the rosacea patients $10 \mathrm{~g}$. of maltose, sucrose, and lactose were given intravenously and separately and the clinical response was observed.

\section{Results}

The results for the control and rosacea groups are given in the Table, which includes for comparison data from two adults with typical lactose intolerance. Disaccharidase units (micro- mols of substrate hydrolysed per minute) are expressed per gramme wet weight of mucosa. The tissue samples weighed from 5 to $53 \mathrm{mg}$.

The control data are relatively homogeneous, though somewhat lower than previously reported (Auricchio et al., 1963; Dahlquist, 1964 ; Sheehy and Anderson, 1965). The maltase: lactase and sucrase: lactase ratios are, however, similar to those reported by others (Auricchio et al., 1963 ; Dahlqvist, 1964 ; Plotkin and Isselbacher, 1964 ; Sheehy and Anderson, 1965). The quotient of these ratios (maltase: lactase $\times$ sucrase: lactase) has also been calculated for comparison.

None of the rosacea subjects has that degree of lactase deficiency found in the two patients with lactose intolerance, but the mean level of 2.2 is significantly lower than the normal mean of $3.4(t=2.27, n=30, P<0.05)$, and there are three individual values $(0.7,0.5$, and 0.3 unit) which are substantially less than the lowest of the normals (1.4 units). Even the level of 1.1 (Case 6) may be low in relation to the maltase and sucrase levels in this patient, and this is where the enzyme activity ratios may give a guide to abnormality, which the absolute values do not. Nevertheless, at worst, no more than $4(20 \%)$ of the 20 rosacea patients have low lactase levels.

The mean values for maltase and sucrase activity are also lower for the rosacea group than for the controls, but do not achieve formal significance. Certain individual maltase levels (4.2, 6.5, and 7.2 units) and certain sucrase levels $(2.2,0.9$, and 1.6) are considerably lower than the lowest of the normal figures (13.4 and 3.5 respectively).

The maltase: lactase and sucrase: lactase ratios are remarkably homogeneous in the control group. The corresponding ratios for Cases 6,12, and 19, particularly when multiplied together, fall substantially outside the normal range, but do not approach the high values of the patients with unequivocal lactose intolerance.

Finally, none of the rosacea patients given intravenous disaccharide experienced symptoms either of facial flushing or of abdominal discomfort.

\section{Discussion}

It seems that some patients with rosacea have some degree of disaccharidase deficiency, especially lactase, but not of the same order of severity as is found in typical cases of adult lactose intolerance. The deficiency is not limited to those with histological evidence of small-bowel disease. On the other hand, there are patients with rosacea and alimentary symptoms who have normal enzyme levels. Therefore, unless the enzyme deficit is intermittent, which seems unlikely, disaccharidase deficiency is not a common explanation for the dyspepsia and diarrhoea which are frequent features of the rosacea syndrome (Eastwood, 1928 ; Watson et al., 1965).

There are species differences in the distribution of the different disaccharidases throughout the small intestine (Dahlqvist, $1961,1963)$, and though direct evidence for this in humans is scanty (Von Euler and Svanberg, 1921 ; Heilskov, 1951), in-

\footnotetext{
* Ure Research Fellow, University Department of Medicine, Royal Infirmary, Glasgow. + Biochemist, Royal Infirmary, Glasgow. $¥$ Senior Lecturer in Medicine, Royal Infirmary, Glasgow.
} 
Clinical and Laboratory Data of 20 Rosacea Patients, 12 Controls, and 2 Patients with Lactose Intolerance due to Alactasia

\begin{tabular}{|c|c|c|c|c|c|c|c|c|c|c|c|}
\hline $\begin{array}{l}\text { Case } \\
\text { No. }\end{array}$ & Sex & $\begin{array}{l}\text { Biopsy } \\
\text { Grade }\end{array}$ & Weight* & Dyspepsia & Diarrhoea & Maltaset & Lactaset & Sucraset & $\begin{array}{l}\text { Maltase/ } \\
\text { Lactase }\end{array}$ & $\begin{array}{l}\text { Sucrase/ } \\
\text { Lactase }\end{array}$ & $M / L \times S / L$ \\
\hline $\begin{array}{r}1 \\
2 \\
3 \\
4 \\
5 \\
6 \\
7 \\
8 \\
9 \\
10 \\
11 \\
12 \\
13 \\
14 \\
15 \\
16 \\
17 \\
18 \\
19 \\
20\end{array}$ & $\begin{array}{c}\mathbf{M} \\
\mathbf{M} \\
\mathbf{F} \\
\mathbf{M} \\
\mathbf{F} \\
\mathbf{F} \\
\mathbf{F} \\
\mathbf{M} \\
\mathbf{M} \\
\mathbf{M} \\
\mathbf{M} \\
\mathbf{M} \\
\mathbf{F} \\
\mathbf{M} \\
\mathbf{M} \\
\mathbf{M} \\
\mathbf{M} \\
\mathbf{F} \\
\mathbf{M} \\
\mathbf{F}\end{array}$ & $\begin{array}{l}1 \\
1 \\
1 \\
1 \\
1 \\
1 \\
1 \\
1 \\
2 \\
2 \\
3 \\
3 \\
3 \\
3 \\
3 \\
4 \\
4 \\
4 \\
5 \\
5\end{array}$ & $\begin{array}{r}-11 \\
-29 \\
-4 \\
+7 \\
-25 \\
+7 \\
-4 \\
+8 \\
-25 \\
+24 \\
-7 \\
+3 \\
+2 \\
-26 \\
-2 \\
+15 \\
-43 \\
-13 \\
-16 \\
-24\end{array}$ & 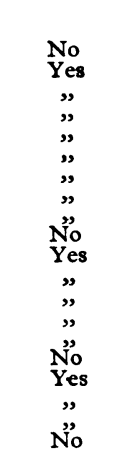 & 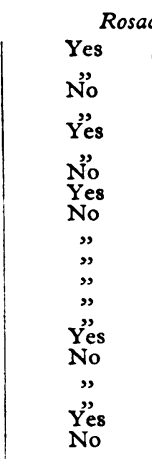 & $\begin{array}{c}\text { Patients } \\
9 \cdot 5 \\
10 \cdot 6 \\
16 \cdot 4 \\
20 \cdot 4 \\
19 \cdot 8 \\
23.0 \\
10 \cdot 6 \\
4 \cdot 2 \\
22 \cdot 0 \\
16 \cdot 7 \\
6.5 \\
7 \cdot 2 \\
26 \cdot 8 \\
12.9 \\
15.9 \\
14 \cdot 4 \\
25 \cdot 0 \\
10 \cdot 7 \\
14 \cdot 4 \\
20.0\end{array}$ & $\begin{array}{l}4 \cdot 8 \\
3 \cdot 1 \\
2 \cdot 9 \\
1 \cdot 7 \\
3 \cdot 1 \\
1 \cdot 1 \\
1 \cdot 2 \\
0 \cdot 7 \\
1 \cdot 6 \\
2 \cdot 3 \\
1 \cdot 1 \\
0 \cdot 3 \\
6 \cdot 0 \\
2 \cdot 2 \\
1 \cdot 5 \\
4 \cdot 4 \\
1 \cdot 6 \\
2 \cdot 0 \\
0 \cdot 5 \\
2 \cdot 8\end{array}$ & $\begin{array}{l}5 \cdot 2 \\
7 \cdot 6 \\
7 \cdot 4 \\
3 \cdot 3 \\
4 \cdot 5 \\
6 \cdot 3 \\
2 \cdot 2 \\
0.9 \\
5 \cdot 2 \\
4 \cdot 1 \\
2 \cdot 8 \\
1.6 \\
6 \cdot 7 \\
3 \cdot 6 \\
3.6 \\
8 \cdot 0 \\
3 \cdot 2 \\
3.1 \\
3.1 \\
6.8\end{array}$ & $\begin{array}{r}2.0 \\
3.4 \\
5.6 \\
12.0 \\
6.4 \\
20.9 \\
8.8 \\
6.0 \\
13.7 \\
7.3 \\
5.9 \\
24.0 \\
4.5 \\
5.9 \\
10.6 \\
3.3 \\
15.7 \\
5.4 \\
28.8 \\
7.1\end{array}$ & $\begin{array}{l}1.1 \\
2.4 \\
2.6 \\
1.9 \\
1.5 \\
5.7 \\
1.8 \\
1.3 \\
3.2 \\
1.8 \\
2.5 \\
5.3 \\
1.1 \\
1.6 \\
2.4 \\
1.8 \\
2.0 \\
1.6 \\
6.2 \\
2.4\end{array}$ & $\begin{array}{r}2 \cdot 2 \\
8 \cdot 4 \\
14 \cdot 3 \\
23 \cdot 2 \\
9 \cdot 3 \\
120 \cdot 0 \\
16 \cdot 1 \\
7 \cdot 8 \\
44 \cdot 5 \\
13 \cdot 0 \\
15 \cdot 0 \\
128 \cdot 0 \\
5 \cdot 0 \\
9 \cdot 7 \\
25 \cdot 4 \\
6 \cdot 0 \\
31 \cdot 4 \\
8 \cdot 4 \\
179 \cdot 0 \\
17 \cdot 3\end{array}$ \\
\hline \multirow{4}{*}{$\begin{array}{l}\mathbf{A} \\
\mathbf{B} \\
\mathbf{C} \\
\mathbf{D} \\
\mathbf{B} \\
\mathbf{P} \\
\mathbf{G} \\
\mathbf{H} \\
\mathbf{I} \\
\mathbf{J} \\
\mathbf{K} \\
\mathbf{L}\end{array}$} & & & & & Mean \pm S.D. & $15 \cdot 4 \pm 6 \cdot 4$ & $2 \cdot 2 \pm 1 \cdot 5$ & $4 \cdot 6 \pm 2 \cdot 1$ & $9 \cdot 9 \pm 7 \cdot 3$ & $2 \cdot 4 \pm 1 \cdot 3$ & $34 \cdot 2 \pm 48 \cdot 9$ \\
\hline & $\begin{array}{c}\mathbf{M} \\
\mathbf{F} \\
\mathbf{M} \\
\mathbf{M} \\
\mathbf{M} \\
\mathbf{M} \\
\mathbf{F} \\
\mathbf{F} \\
\mathbf{M} \\
\mathbf{F} \\
\mathbf{M} \\
\mathbf{M}\end{array}$ & $\begin{array}{l}1 \\
1 \\
1 \\
2 \\
1 \\
1 \\
1 \\
1 \\
1 \\
2 \\
1 \\
1\end{array}$ & & Nil & Nil & $\begin{array}{c}\text { mtrols } \\
13.4 \\
14.0 \\
19.6 \\
16.6 \\
26.4 \\
27.2 \\
15.0 \\
21.0 \\
13.7 \\
33.6 \\
17.9 \\
21.6\end{array}$ & $\begin{array}{l}1.6 \\
1.4 \\
3.1 \\
2.5 \\
4.9 \\
5.4 \\
2.5 \\
3.5 \\
2 \cdot 1 \\
6.8 \\
2.9 \\
4 \cdot 2\end{array}$ & $\begin{array}{r}3.6 \\
4.3 \\
4.4 \\
5.3 \\
6.6 \\
7.5 \\
3.5 \\
5.8 \\
5.1 \\
10.9 \\
4.2 \\
6.0\end{array}$ & $\begin{array}{r}8.4 \\
10.0 \\
6.3 \\
6.7 \\
5.4 \\
5.0 \\
6.0 \\
6.0 \\
6.5 \\
4.9 \\
6.2 \\
5.1\end{array}$ & $\begin{array}{l}2.3 \\
3.1 \\
1.4 \\
2.1 \\
1.3 \\
1.4 \\
1.4 \\
1.7 \\
2.4 \\
1.6 \\
1.4 \\
1.4\end{array}$ & $\begin{array}{r}18.9 \\
31.0 \\
8.9 \\
14.1 \\
7.3 \\
7.0 \\
8.4 \\
10.2 \\
15.8 \\
7.8 \\
8.7 \\
7.1\end{array}$ \\
\hline & & . & & & Mean \pm S.D. & $20 \cdot 0 \pm 6 \cdot 4$ & $3.4 \pm 1.7$ & $5 \cdot 6 \pm 2 \cdot 1$ & $6 \cdot 4 \pm 1 \cdot 5$ & $1.8 \pm 0.5$ & $12 \cdot 3 \pm 7 \cdot 1$ \\
\hline & $\begin{array}{l}\mathbf{F} \\
\mathbf{M}\end{array}$ & $\begin{array}{c}\text { U. } \\
1\end{array}$ & & $\begin{array}{c}\text { Yes } \\
\text { ", }\end{array}$ & $\begin{array}{r}\text { Yes }\left\{\begin{array}{l}1 \\
2 \\
2 \\
3\end{array}\right. \\
\text { Yes }\end{array}$ & $\begin{array}{c}\text { Intolerance } \\
13.5 \\
15.7 \\
11.2 \\
16.0\end{array}$ & $\begin{array}{l}0 \cdot 2 \\
0 \cdot 0 \\
0 \cdot 0 \\
0 \cdot 2\end{array}$ & $\begin{array}{l}3 \cdot 9 \\
4 \cdot 0 \\
2 \cdot 7 \\
3 \cdot 5\end{array}$ & $\begin{array}{l}67 \cdot 5 \\
80 \cdot 0\end{array}$ & $\begin{array}{l}19.5 \\
17.5\end{array}$ & $\begin{array}{l}1,320 \\
1,400\end{array}$ \\
\hline
\end{tabular}

Weight given as pounds above or below average for age, height, and sex (Society of Actuaries, 1959).

Units of activity/g. wet weight of tissue.
U. = Unusual biopsy, subject of forthcoming case report.

direct evidence, on the basis of the differential absorption of disaccharidases along the small bowel (Dahlqvist and Borgstrom, 1961), suggest that it is so. Therefore it is important that in comparative studies of disaccharidase activity strict attention is given to obtaining tissue samples from similar segments of the small bowel. This omission from the study by Sheehy and Anderson (1965) may account for the wide range of enzyme levels which they obtained. In the present study all pieces of tissue were taken from the first $20 \mathrm{~cm}$. of jejunum.

Further, when enzyme activity is related to wet tissue weight it is important to adopt a uniform technique. After initial experimentation (Watson and Murray, 1965) we satisfied ourselves that the most uniform procedure was as described in this report. Direct pressure blotting has no uniform end-point short of complete denudation of epithelium. These technical considerations may explain why our control values are lower and fall within a narrower range than the results of others.

One of the consequences of disaccharidase deficiency seems to be a greater absorption of disaccharide (Santini et al., 1960); but even if this were to occur in people with rosacea it is clear from the intravenous studies with disaccharide that it would be unlikely to be the cause of either their facial or abdominal symptomatology.

\section{Summary}

Intestinal disaccharidase activity was measured in 20 patients with rosacea. They were selected to give proportional representation of the five categories of jejunal histology found in rosacea, and $17(85 \%)$ had dyspepsia or diarrhoea or both.
The results show that some degree of enzyme deficiency, particularly of lactase, occurs in rosacea, but is not sufficiently common or severe to account for the high incidence of abdominal symptomatology.

Studies with intravenous disaccharide infusions show that the facial flush in rosacea is not caused or aggravated by circulating disaccharide.

This work was supported in part by the Scottish Hospitals Endowment Research Trust (grant No. 164).

\section{REFERENCES}

Auricchio, S., Rubino, A., Landolt, M., Semenza, G., and Prader, A. (1963). Ĺancet, 2, 324

Dahlqvist, A. (1961). Biochem. f., 78, 282.

- (1963). Ibid. 86, 72 .

- (1964). In Disorders Due to Intestinal Defective Carbohydrate Digestion, edited by P. Durand. Rome.

- and Borgstrom, B. (1961). Biochem. F., 81, 411.

Durand, P. (1958). Minerva pediat., 10, 706.

Eastwood, S. R. (1928). Brit. F. Derm. Syph., 40, 91, 148.

Heilskov, N. S. C. (1951). Acta physiol scand., 24, 84.

Kendall, A. I. (1926). F. Amer. med. Ass., 86, 737.

Kern, F., Struthers, J. E., and Attwood, W. L. (1963). Gastroenterology, $45,477$.

McMichael, H. B., Webb, J., and Dawson, A. M. (1965). Lancet, 1, 717. Miller, D., and Crane, R. K. (1961). Biochem. biophys. Acta (Amst.) 52, 281, 293

Plotkin, G. R., and Isselbacher, K. J. (1964). New Engl. f. Med., 271, 1033.

Santini, R., iun., Aviles, J., and Sheehy, T. W. (1960). Amer. f. dig. Dis., 5, 1059 .

Sheehy, T. W., and Anderson, P. R. (1965). Lancet, 2, 1.

Stokes, J. H., and Beerman, H. (1932): Arch. Derm. Syph. (Chic.), 26,

Von Euler, H., and Svanberg, O. (1921). Z. physiol. Chem., 115, 43.

Watson, W. C., and Murray, E. (1965). Unpublished observations.

Waton, E., and Murray, D. (1965). Lancet, 2, 47. 